\title{
2011 APSA Teaching and Learning Conference Track Summaries
}

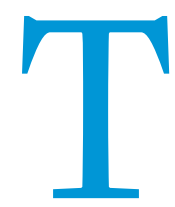

he eighth annual APSA Teaching and Learning Conference (TLC) was held in Albuquerque, New Mexico, February 11-13, 2011, with 226 attendees onsite. The theme for the meeting was "Making Sense of Politics and Political Science." Using the workinggroup model, the TLC track format encourages in-depth discussion and debate on research dealing with the scholarship of teaching and learning.

In addition to the 13 working groups, there were 20 workshops on various topics. The 2011 TLC also featured plenary events, including a lunchtime roundtable on "Strategies for Teaching Challenging Issues" and the Pi Sigma Alpha Keynote Address, entitled "Helping Students Make Sense of a Changing Political World," delivered by Professor Jane Y. Junn of the University of Southern California. The meeting concluded on Sunday morning with a plenary session in which the attendees discussed "Where Do We Go from Here?" and offered concrete suggestions on next steps for enhancing teaching and learning throughout the discipline and within their own academic communities.

As was the case at the 2010 conference, the 2011 TLC featured live remote participation technology. Through the use of remote participation, the three plenary sessions were broadcast live via the Internet, allowing those who were unable to attend the meeting to join discussion virtually. This technology was made available by Professor Derrick Cogburn and his lab, COTELCO (Syracuse University and American University). The sessions are currently available at http://www.apsanet.org/content_69203.cfm.

APSA would like to thank the following individuals who served on the 2011 TLC Programming Committee and as track moderators:

- Mitchell Brown (chair), Auburn University (Teaching Research Methods)

- Derrick Cogburn, American University (Integrating Technology)

- Jeffrey S. Lantis, College of Wooster (Internationalizing the Curriculum II)

- Erin Richards, Cascadia Community College (Core Curriculum/General Education)

- Stephen Salkever, Bryn Mawr College (Teaching Theory and Political Theories)

- Deborah Ward, Rutgers University (Internationalizing the Curriculum I)

The following seven individuals also served as 2011 track moderators: Victor Asal, SUNY University of Albany (Simulations and Role Play I); Elizabeth Bennion, Indiana University South Bend (Civic Engagement II); Boris Ricks, University of California, Northridge (Diversity, Inclusiveness, and Equality); Ronald Shaiko, Dartmouth College (Civic Engagement I); Daniel E. Smith, Northwest Missouri State University (Simulations and Role Play I); John Ishiyama, University of North Texas (Graduate Education and
Professional Development); and Candace C. Young, Truman State University (Program Assessment).

\section{The 2012 APSA Teaching and Learning Conference}

The 2012 TLC will be held in Washington, DC, February 17-19, 2012, at the Grand Hyatt Washington. For more information on the call for proposals and registration, please visit http://www. apsanet.org/teachingconference.

\section{TLC Track Summaries}

The following TLC track summaries were written by 2011 TLC track participants and detail the key themes that emerged in each track. We hope that you find the information on and insights into teaching political science to be useful.

Kimberly A. Mealy, Director of Education, Professional Development, and Diversity Programs

\section{TRACK: CIVIC ENGAGEMENT I: EXPERIENTIAL} LEARNING/LEARNING COMMUNITIES

\section{S. Suzan J. Harkness, University of the District of Columbia \\ Michael Kuchinsky, Gardner Webb University \\ Christine Pappas, East Central University}

In 2004, 40 political scientists gathered in Washington, DC, to inaugurate the APSA Teaching and Learning Conference (TLC), which aimed to explore how we teach and how students learn best within the discipline. A common theme linking the activebased curriculum to political science over the past eight years has been the theory of experiential education. Over time, the vibrant conversation within this track has included community-based learning, service learning, civic engagement, community-based research, simulations, case studies, problem-based learning, and internships. The discourse has also shifted away from asking what civic engagement is and how we can integrate it into the curriculum toward questions such as:

- How do we assess and document learning?

- What is the long-term impact of civic engagement?

- What are the affordances to all participants?

- What constitutes success?

- What is more important, political engagement or civic engagement?

- What models can measure efficacy?

- Can we develop systematic standards?

- Is there a bias within the framework of some experiential education that favors more affluent students?

- Do traditional students', nontraditional students', and faculty's definitions of what constitutes political and civic engagement fall within the same realm of activities? 